補綴誌，J Jpn Prosthodont Soc, 42: 815〜822, 1998.

\title{
原著論文
}

\section{義歯修理におけるバルビツール酸誘導体を用いた 常温重合レジンと床用レジンとの接着性}

\author{
清水 博史 吉永 正治 羽生 哲也 高橋 裕
Bond Strength of a Self-curing Resin with Barbituric Acid Derivatives to a Few Kinds of Denture Base Resin in Denture Repair

Hiroshi Shimizu, Masaharu Yoshinaga, Tetsuya Habu and Yutaka Takahashi

\begin{abstract}
A secure bond between self-curing resin and denture base resin is necessary for clinical success in denture repair. This study was conducted to evaluate the bond strengths of a new self-curing resin with barbituric acid derivatives to pour-type denture base resin, heat-cured resin and microwave-cured resin and investigate the effect of surface treatment. The repair surfaces of test specimens were treated in various manners before self-curing resin was applied to the joint. A three-point loading test was carried out to determine the transverse strength of specimens, and the surfaces of the three kinds of denture base resin after surface treatment were observed with a scanning electron microscope.
\end{abstract}

The results were as follows:

1. The surface treatment with dichloromethane following alumina air abrasive was the most effective on the three kinds of denture base resin.

2. The bond strength of a new self-curing resin with barbituric acid derivatives was weaker than that of conventional self-curing resin to denture base resins without any surface treatment.

3. The effects of any surface treatment with a new self-curing resin with barbituric acid derivatives were inferior to those with conventional resin.

Key words: denture repair, self-curing resin, barbituric acid derivative, surface treatment, transverse strength

\section{I. 緒言}

著者らは, 義歯床の修理を想定して, 床用レジンに常温 重合レジンを強固に接着させる表面処理法について検討し ている( ${ }^{1-3)}$ が，これまでは過酸化ベンゾイル（BPO）と芳 香族第 3 級アミンのジメチルパラトルイジン (DMPT) の反応により硬化が始まる, いわば従来型の常温重合レジ ンを修理用レジンとして用いてきた。

福岡歯科大学歯科補綴学第 1 講座（主任：羽生哲也教授)

Department of Removable Prosthodontics, Fukuoka Dental College (Chief : Prof. Tetsuya Habu)

平成 10 年 4 月 1 日受付
一方, 近年硬化物の色調変化の改善を主な目的として, バルビツール酸誘導体，第 4 級アンモニウム塩および有機 金属化合物の 3 元系触媒を採用した新しい常温重合レジ ン ${ }^{4-6)}$ が市販され, 臨床で急速に普及したようであるが, さらに改良が検討されている ${ }^{7.8)}$ ところである.

このレジンは色調の経時的変化が少なく, 機械的強さは 市販されている各種の常温重合レジンとほほ同程度で, 適 合性はより優れているが, 床用レジンとの接着性には改良 する点があるらと指摘されている.

そこで，本研究はこのバルビツール酸誘導体を触媒系に 用いた常温重合レジンと重合様式の異なる 3 種類の床用レ ジンとの接着性を検討し, さらにより強固に接着させる表 面処理法を見い出そうとするものである. 


\section{II. 実験材料と方法}

\section{1. 試料の作製}

試料は JIS 規格の抗折たわみ試験（JIS T 6501）に準じ て作製した。

流し込みレジンのポアーレジン P (ロット番号 089402 (粉), 069298 (液), 松風社, 以下 PR と略号で記 載) と加熱重合レジンのアクロン（ロット番号 240971 (粉)，260971 (液), ジーシー社, 以下 AC) は, 既報3で述べた方法で重合した。

マイクロウェーブ重合レジンのアクロン MC (ロット番 号 221281 (粉), 130151（液), ジーシー社, 以下 MC) は, FRP フラスコ (ジーシー社) 中の石靔の陰型内に メーカー指示の粉液比で混和したレジンを填入し, 電子レ ンジ（EM-M $535 \mathrm{~T}$, 出力 $500 \mathrm{~W}$, サンョー社）内で 3 分 間9.10)マイクロウェーブ照射した後, 室温まで放冷して 12 時間後にレジン片を取り出した。

3 種類のレジン片は，耐水ペーパーを順次用いて注水下 にて研磨, 整形し, $37^{\circ} \mathrm{C}$ 温水中に 3 週間以上浸漬した。

各レジン片は中央を切断し，切断面を\# 1,000 の耐水 ペーパーで研磨，整形して新鮮面を出した。一部の試料は このまま用い，\#1,000 群とした。残りの試料は既報)と 同様の方法で艶出し研磨を行った。一部の試料はこの状態 で用い，Polish 群とした。さらに残りの試料はこの面に 対し種々の表面処理を行い，それぞれの実験群に分けた。 表 1 に実験群の略号と各表面処理法を示した。

石膏モールド上で切断面間に $3 \mathrm{~mm}$ のスペースを設け, 常温重合レジンのュニファスト II（ロット番号 010251 (粉)，101172（液)，ジーシー社，以下 UF II）を 用い筆積み法にてこのスペースを填塞した。従来型のユニ ファスト (ジーシー社, 以下 UF) (現在はユニファスト トラッドとして市販されている）は，前述のように触媒系 として粉末に BPO, 液体に第 3 級アミンの DMPT が含 まれているのに対し，UF II は粉末にバルビツール酸誘導 体の 1-Cyclohexyl-5-Ethylpyrimidinetrione, 液体に 4 級アンモニウム塩の Diauryl dimethyl ammoniumchlorideが含まれている゙点が異なっている。レジンの硬化後
に,\#1,000の耐水ペーパーで最終的に $68 \times 10 \times 2.5 \mathrm{~mm}$ の寸法に仕上げ，試料とした．参考のため， 3 種類の床用 レジン単体の試料 $(65 \times 10 \times 2.5 \mathrm{~mm})$ も作製した。試料 の個数は各条件ごとに 5 個とした。

\section{3 点曲げ試験}

すべての試料は, 完成後 $37^{\circ} \mathrm{C}$ 温水中に 24 時間浸漬した 後, 3 点曲げ試験を行った．測定には万能引張り圧縮試験 機 TCM 200 （ミネベア社）を用い, 支点間距離 $50 \mathrm{~mm}$, クロスヘッドスピード $5 \mathrm{~mm} / \mathrm{min}$ の条件下で, UF II の修 理部中央に圧縮荷重を加え，破断時の荷重から 3 点曲げ強 さを算出した。また，破断時のたわみ量を応力一時間曲線 とチャートスピードから算出した。得られた測定值の平均 值と標準偏差を求めた後，条件ごとに平均值の差の $\mathrm{t}$ 検定 を行った.

試験後に試料の破断状況を肉眼にて観察し，分類した。

\section{3. 各表面処理後の床用レジン表面性状の SEM 観察} 3 種類の床用レジンに各種の表面処理を行い，走査型電 子顕微鏡 JSM-T 330 （日本電子社）を用いて, 加速電圧 5 $\mathrm{kV}$ にてその表面性状を観察した。

\section{III. 結 果}

\section{3 点曲げ試験}

3 点曲げ強さの結果を図 1〜3に示した.

$\mathrm{PR}$ では, $\mathrm{SB} ・ \mathrm{DM}$ 群 $(48.3 \pm 6.2 \mathrm{MPa})$ が最も大き く, 次いで DM・MMA群 $(36.4 \pm 7.8 \mathrm{MPa})$ と $\mathrm{SB}$ 群

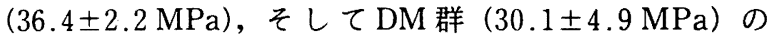

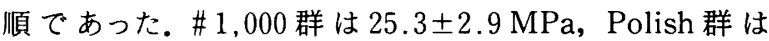
$15.5 \pm 4.4 \mathrm{MPa}$ であった。

$\mathrm{AC}$ は PR と類似の傾向で, $\mathrm{SB} \cdot \mathrm{DM}$ 群 $(48.7 \pm 4.4$ $\mathrm{MPa}$ )が最も大きく，次いで DM・MMA 群 $(38.8 \pm 10.4$ $\mathrm{MPa})$ と $\mathrm{SB}$ 群 $(41.2 \pm 6.2 \mathrm{MPa})$, そして DM 群

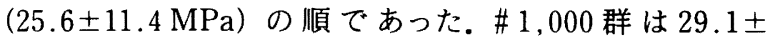
$3.9 \mathrm{MPa}$ ，Polish 群は $20.6 \pm 5.7 \mathrm{MPa}$ であった.

$\mathrm{MC}$ は他の 2 種類と傾向が異なっておう, $\mathrm{SB} ・ \mathrm{DM}$ 群 $(51.9 \pm 3.9 \mathrm{MPa})$ と $\mathrm{SB}$ 群 $(49.5 \pm 8.3 \mathrm{MPa})$ が最も大

表 1 Experimental groups and surface treatment methods 実験群と表面処理法

\begin{tabular}{|c|c|}
\hline 実 験 群 & 决表 面 処 理 法 \\
\hline $\mathrm{SB} \cdot \mathrm{DM}$ & 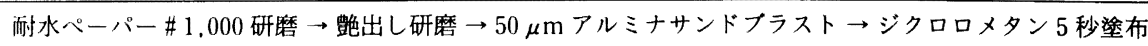 \\
\hline $\mathrm{DM} \cdot \mathrm{MMA}$ & 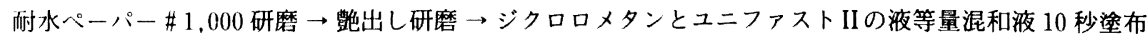 \\
\hline $\mathrm{SB}$ & 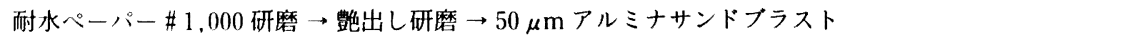 \\
\hline $\mathrm{DM}$ & 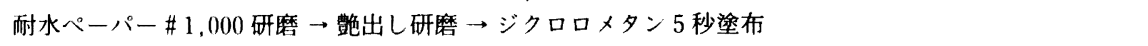 \\
\hline$\# 1,000$ & 耐水ペーパー\#1,000 研磨 \\
\hline Polish & 耐水ペーパー\# 1,000 研磨 $\rightarrow$ 敳出し研磨 \\
\hline
\end{tabular}




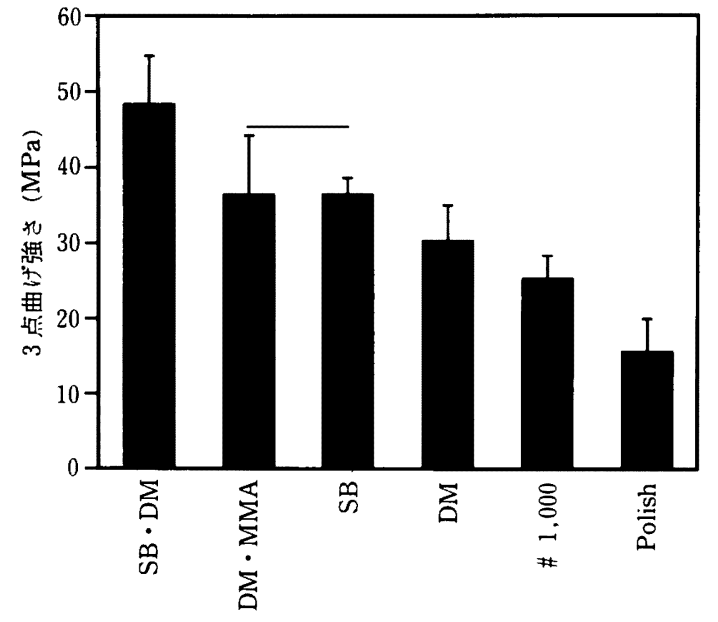

图 1 Effect of surface treatments on transverse strengths of a pour-type denture base resin after repair with a self-curing resin with barbituric acid derivatives Horizontal bars connect mean values that do not differ statistically significantly $(\mathrm{p}<0.05)$ 表面処理がバルビッール酸誘導体を用いた常温重合レジ ンで修理後の流し込みレジンの曲げ強さに及ほす影響 線で結んだ簓所は危険率 5\% で統計的有意差がない

きく, 次いで DM・MMA 群 $(29.3 \pm 7.8 \mathrm{MPa})$ と DM 群

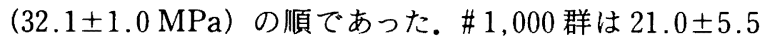

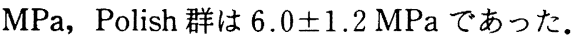

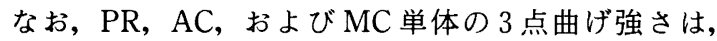

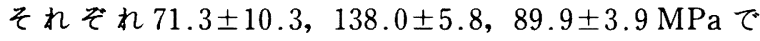
あった。

破断時のたわみ量の結果を図 4〜6に示した.いずれの 床用レジンにおいても，值の優劣はそれぞれの 3 点曲げ強 さの結果と類似の傾向であった。

$\mathrm{PR}$ では, SB・DM 群 $(3.9 \pm 0.8 \mathrm{~mm})$ が最も大きく， 次いで DM・MMA 群 $(3.0 \pm 0.5 \mathrm{~mm})$ と SB 群 $(2.6 \pm$ $0.2 \mathrm{~mm})$, そして DM 群 $(2.2 \pm 0.4 \mathrm{~mm})$ の順であった. \#1,000群は $1.8 \pm 0.1 \mathrm{~mm}$, Polish 群は $1.1 \pm 0.3 \mathrm{~mm}$ で あった。

$\mathrm{AC}$ では, $\mathrm{SB} ・ \mathrm{DM}$ 群 $(3.2 \pm 0.3 \mathrm{~mm}), \mathrm{DM} ・ \mathrm{MMA}$ 群 $(2.8 \pm 0.6 \mathrm{~mm})$ および $\mathrm{SB}$ 群 $(2.9 \pm 0.5 \mathrm{~mm})$ が大きく, そして DM 群 $(1.7 \pm 0.8 \mathrm{~mm})$ の順であった。 DM 群と\# 1,000 群 $(1.9 \pm 0.1 \mathrm{~mm})$ との間に有意差はみられなかっ た. Polish 群は $1.3 \pm 0.3 \mathrm{~mm}$ であった.

$\mathrm{MC}$ は, SB・DM 群 $(3.8 \pm 0.3 \mathrm{~mm})$ と $\mathrm{SB}$ 群 $(3.5 \pm$

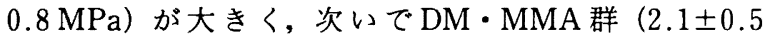
$\mathrm{mm})$ と DM 群 $(2.1 \pm 0.0 \mathrm{~mm})$ の順であった. \#1,000 群は $1.5 \pm 0.4 \mathrm{~mm}$, Polish 群は 0.5 $0.1 \mathrm{~mm}$ であった。

なお， $\mathrm{PR}, \mathrm{AC}$ おび $\mathrm{MC}$ 単体のたわみ量は，それぞ れ $7.4 \pm 1.1,5.7 \pm 0.8,8.3 \pm 1.0 \mathrm{~mm}$ であった。

破断状況を肉眼的に分類した結果を表 2 に示した。 ほと んどの破断は床用レジンと UF II の界面破壊か UF IIの一

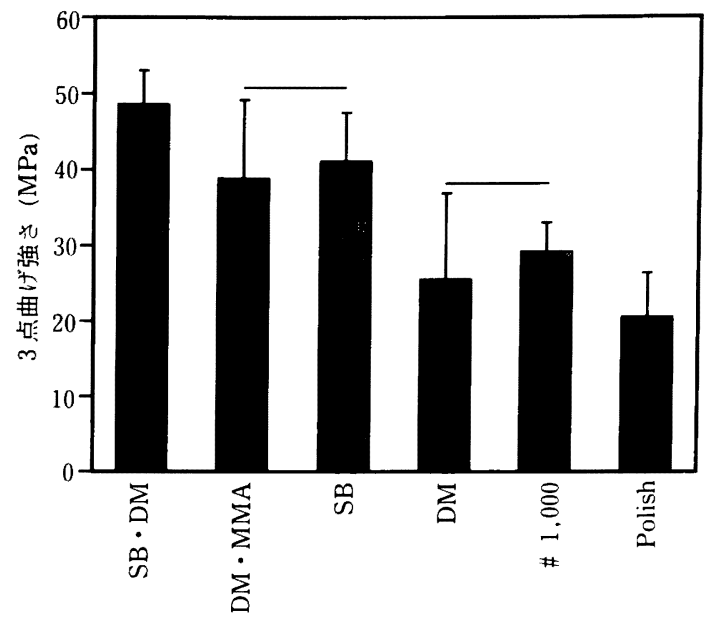

国 2 Effect of surface treatments on transverse strengths of a heat-cured denture base resin after repair with a self-curing resin with barbituric acid derivatives Horizontal bars connect mean values that do not differ statistically significantly $(\mathrm{p}<0.05)$ 表面処理がバルピツール酸誘導体を用いた常温重合レジ ンで修理後の加熱重合レジンの曲げ強さに及ほす影響 線で結んた箇所は危険率 5\% で統計的有意差がない

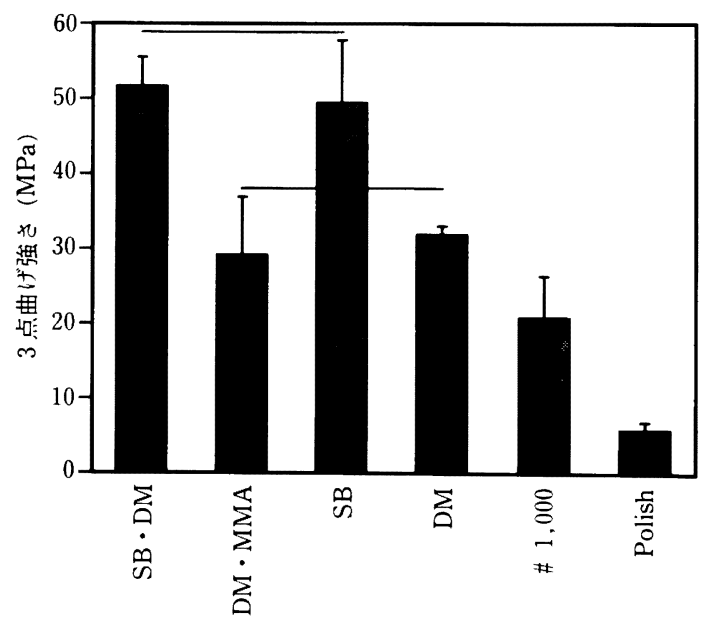

图 3 Effect of surface treatments on transverse strengths of a microwave-cured denture base resin after repair with a self-curing resin with barbituric acid derivatives

Horizontal bars connect mean values that do not differ statistically significantly $(\mathrm{p}<0.05)$ 表面処理がパルビツール酸誘導体を用いた常温重合レジ ンで修理後のマイクロウェーブ重合レジンの曲げ強さに 及ぼす影響

線で結んだ箇所は危険率 5\%で統計的有意差がない

部を含んだ凝集破壊の様相で，荷重の負荷された UF II 中 央での破断は 3 例にみられた。 


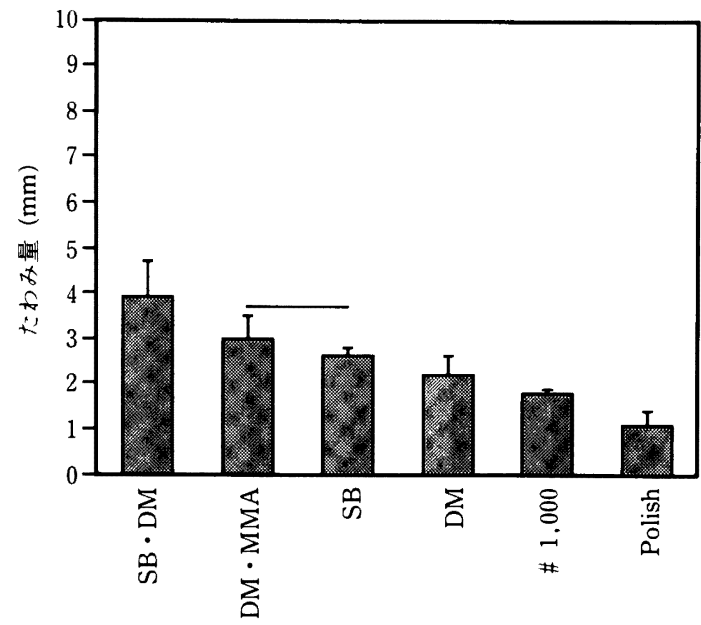

目 4 Effect of surface treatments on maximum deflections of a pour-type denture base resin after repair with a self-curing resin with barbituric acid derivatives Horizontal bars connect mean values that do not differ statistically significantly $(\mathrm{p}<0.05)$ 表面処理がバルビッール酸誘導体を用いた常温重台レジ ンで修理後の流し込みレジンのたわみ量に及ほす影響 線で結んだ䇢所は危険率 5\%で統計的有意差がない

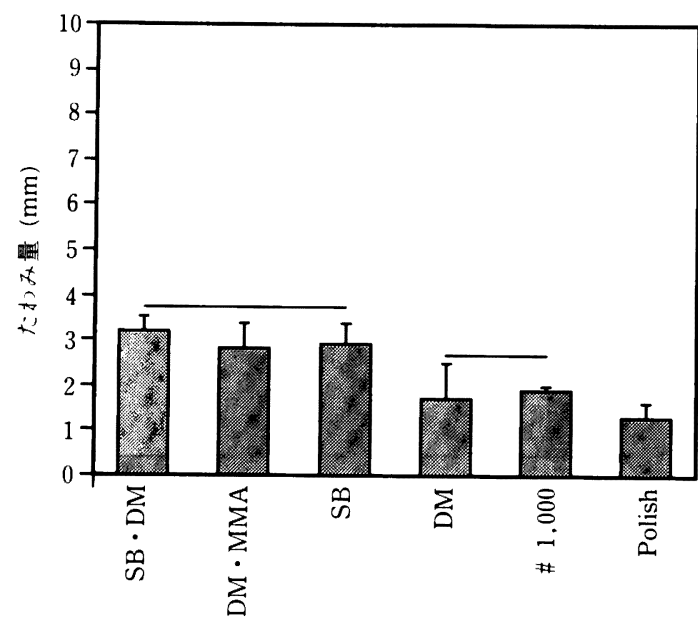

图 5 Effect of surface treatments on maximum deflections of a heat-cured denture base resin after repair with a self-curing resin with barbituric acid derivatives Horizontal bars connect mean values that do not differ statistically significantly $(\mathrm{p}<0.05)$ 表面処理がバルピツール酸誘導体を用いた常温重合レジ ンで修理後の加熱重合レジンのたわみ量に及ほす影響 線で結んた箇所は危険率 5\%で統計的有意差がない

\section{2. 各表面処理後の床用レジン表面性状の SEM 観察}

代表例として ACの\# 1,000 群, Polish 群, SB 群およ び SB・DM 群の 2,000 倍の SEM 像を図 7 に示した. 床用 レジンの種類による相違は観察されなかったので，他の 2 種類は割愛した。 なお, 他と同様 $\mathrm{AC}$ の DM・MMA 群と
42 巻 5 号 (1998)

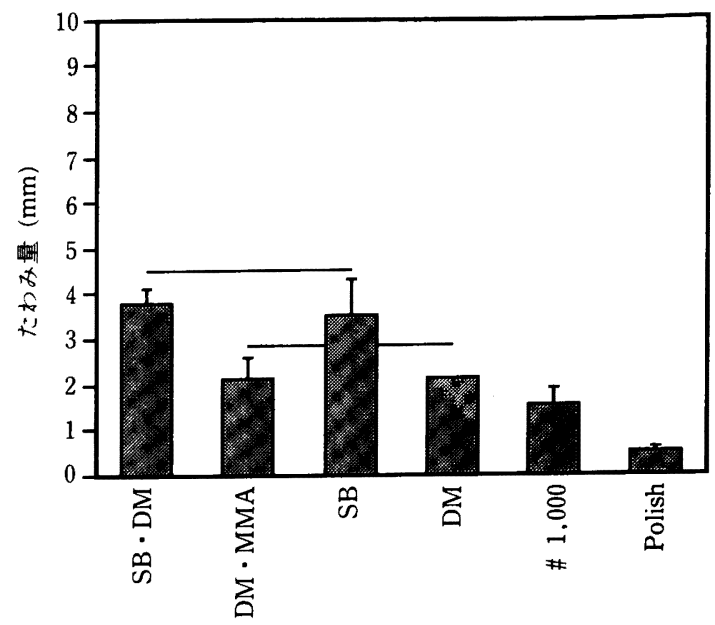

图 6 Effect of surface treatments on maximum deflections of a microwave-cured denture base resin after repair with a self-curing resin with barbituric acid derivatives

Horizontal bars connect mean values that do not differ statistically significantly $(\mathrm{p}<0.05)$

表面処理がバルビツール酸誘導体を用いた常温重合レジ ンで修理後のマイクロウェーブ重合レジンのたわみ量に 及ほす影響

線で結んだ箇所は危険率 $5 \%$ で統計的有意差がない

表 2 Grouping of fracture sites of test specimens (the number of specimens) 試料の破断面の分類（試料の個数）

\begin{tabular}{|c|c|c|c|c|c|c|c|c|c|}
\hline \multirow[t]{3}{*}{ 実 験 群 } & \multicolumn{9}{|c|}{ 床用 レジンの種 類 } \\
\hline & \multicolumn{3}{|c|}{ 流し込み } & \multicolumn{3}{|c|}{ 加熱重合 } & \multicolumn{3}{|c|}{ マイクロウェーブ } \\
\hline & 界面 & 混合 & 凝集 & 界面 & 混合 & 凝集 & 界面 & 混合 & 凝集 \\
\hline $\mathrm{SB} \cdot \mathrm{DM}$ & 0 & 4 & 1 & 0 & 4 & 1 & 0 & 4 & 1 \\
\hline $\mathrm{DM} \cdot \mathrm{MMA}$ & 2 & 3 & 0 & 2 & 3 & 0 & 2 & 3 & 0 \\
\hline SB & 0 & 5 & 0 & 0 & 5 & 0 & 0 & 5 & 0 \\
\hline DM & 2 & 3 & 0 & 3 & 2 & 0 & 3 & 2 & 0 \\
\hline$\# 1,000$ & 5 & 0 & 0 & 5 & 0 & 0 & 5 & 0 & 0 \\
\hline Polish & 5 & 0 & 0 & 5 & 0 & 0 & 5 & 0 & 0 \\
\hline
\end{tabular}

$\mathrm{DM}$ 群の SEM 像は, SB・DM 群と同一の像であったの で,これらも割愛した。

\#1,000 群は, 研磨時に耐水ペーパーの粒子によってつ いたと思われる平行な線条がみられ，粗糙な面を呈してい る. Polish 群は, 研磨の効果を反映してのっぺりとした 平らな像である. $\mathrm{SB}$ 群は,アルミナ粒子によって研削さ れた粗䊁で不規則な面になっている. SB・DM 群は SB 群 とまったく異なり，規則正しい多孔質な性状に変わってい る. 強拡大で観察すると, 図 8 に示したように孔の形状や 大きさはややまちまちである．また，孔の形成されていな い部分は非常に平らな面となっている. 
a
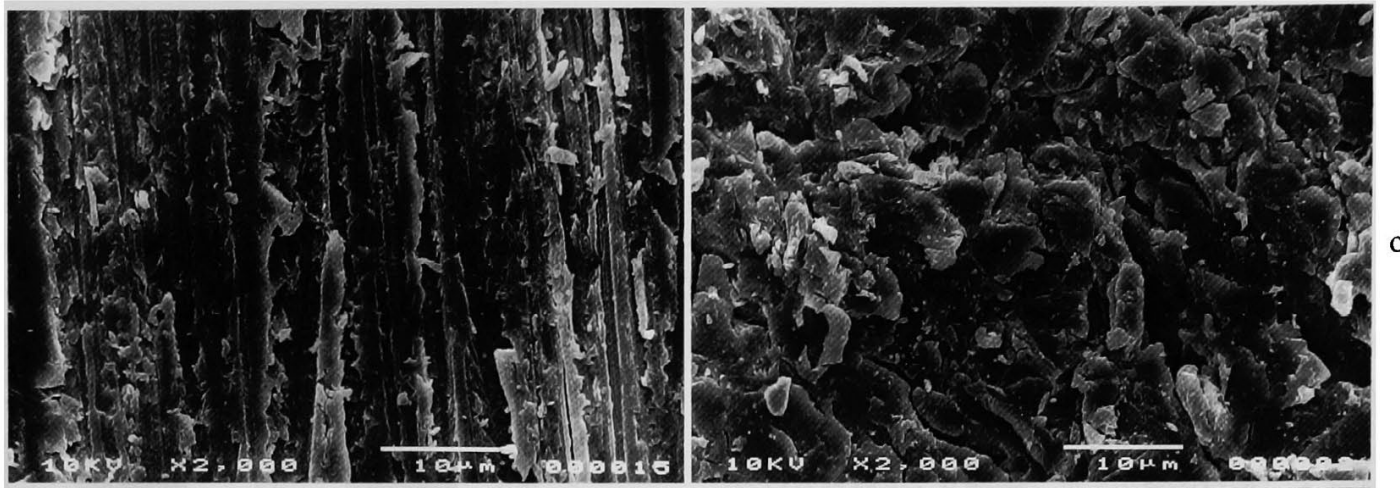

$\mathrm{b}$
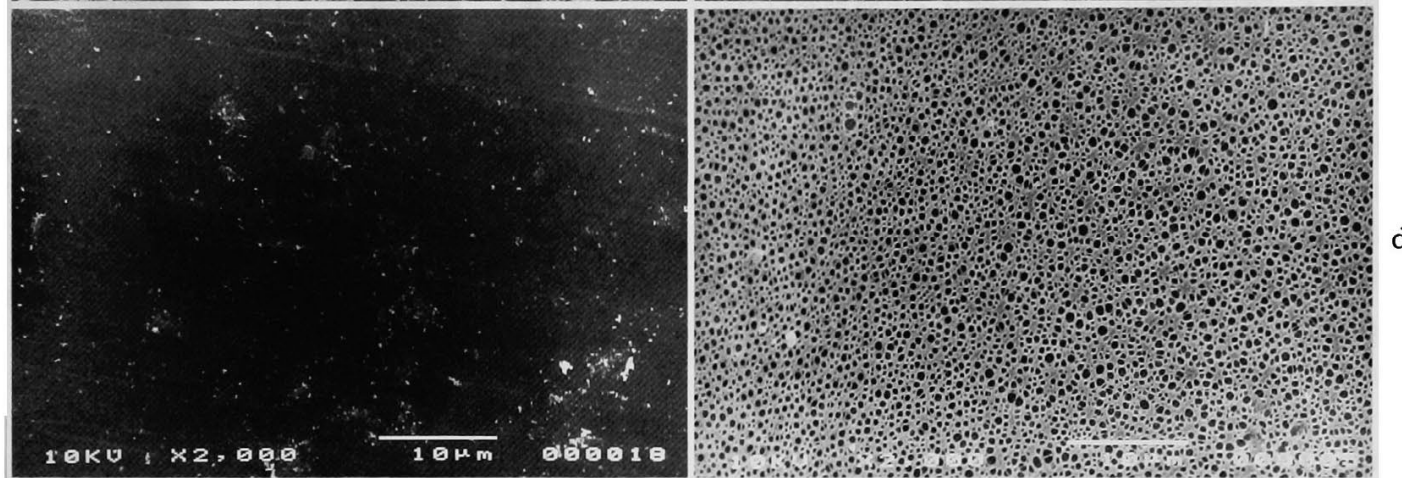

図 7 SEM images of surfaces of a heat-cured denture base resin after a few surface treatments

(Original magnification $\times 2,000$ )

a : Abraded surface with \#1,000 emery paper

b : Final polished surface

c : Air abrasive surface with alumina

d : Treated surface with dichloromethane followed alumina air-abrasive 表面処理後の加熱重合レジンの表面性状の SEM 像（倍率 2,000 倍）

a : \#1,000 耐水ペーパー研磨面

b : 艶出し研磨面

c：アルミナサンドブラスト処理面

$\mathrm{d} ：$ アルミナサンドブラスト・ジクロロメタン処理面

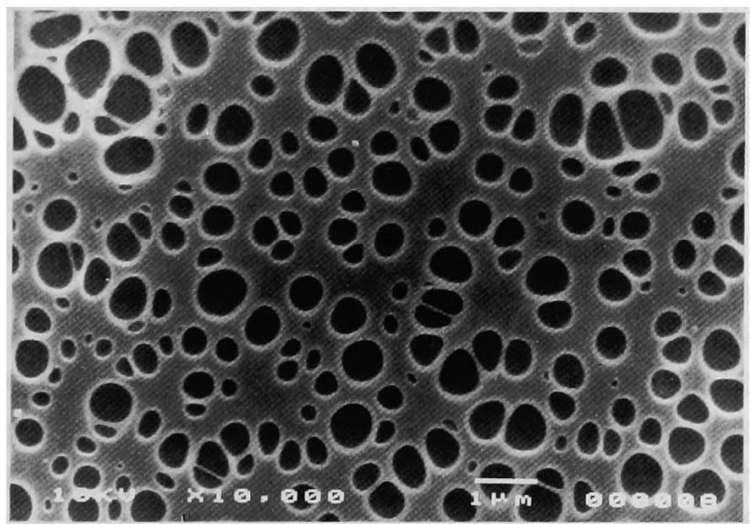

图 8 SEM image of surface of a heat-cured denture base resin after surface treatment with dichloromethane followed alumina air-abrasive (Original magnification $\times 10,000$ ) アルミナサンドブラスト・ジクロロメタン処理後の加熱重合 レジンの表面性状の SEM 像（倍率 10,000 倍）

\section{IV. 考 察}

床用レジンの修理を想定したレジン同士の接着を評価す る場合, 引張り試験では床用レジン本体で破断する説明の 困難な例がみられ ${ }^{1,2)}$, さらに規制の難しい荷重方向のず れが結果に大きく影響する。剪断接着試験では床用レジン 本体がえぐり取られたような特異的な様式で破断する例が 多く ${ }^{3)}$, これも界面の接着強さの評価には適していない. これらに対し，3点曲げ試験はほとんどの例で測定值の優 劣を裏づける破断状況を示し3), 最も適切と思われたので この評価法で判定した.

今回も研磨材が付着したままの被着面に対して表面処理 を行ったので, 常温重合レジンが接着しにくい苛酷な条件 となっている. 一方, 臨床では義歯の修理に先立ち, 破損 部周辺を一層研削して新鮮面を露出させることが多いの で，これを想定した耐水ペーパーの\#1,000 で研磨した面 
についても比較, 検討した.

今回は, $\mathrm{SB} \cdot \mathrm{DM}$ 群と $\mathrm{DM} ・ \mathrm{MMA}$ 群の 2 つの実験群を 新たに設定した。前者には, UF と床用レジンの接着に際 して, 単独でそれぞれ効果のみられたサンドブラスト処 理 ${ }^{3)}$ とジクロロメタン 5 秒処理 ${ }^{2,3)}$ を併用することにより， さらに大きな効果を期待した. 後者には, Rupp ら“の報 告を参考に, ジクロロメタンの効果とUF II の液による浸 透性の向上などを期待した. ジクロロメタンの含有量が $1 / 2$ となるので, 処理時間は 2 倍の 10 秒とした.

UF II を用いて修理を行う場合， 3 種類の床用レジンい ずれに対しても, 破折面周辺にサンドブラスト処理を行っ た後に，さらにジクロロメタン 5 秒処理を施すのが最も効 果的であることがわかった. 床用レジンの種類によって は, SB 群や DM・MMA 群にもある程度の効果がみられ た。

SB 群については, アルミナ粒子による表面の粗䊁化に よって機械的結合力が強化されたことや表面積が増加した ことなどが関与しているものと考えられる。この後にジク ロロメタン処理を施すことによって，粗䊁化された面を残 しつつさらに表面が多孔質になったものと予想された。し かしながら SEM 像を観察すると， SB・DM群，DM・ MMA 群および DM 群の 3 者は, 3 種類の床用レジンい ずれに対しても，予想に反して平らな表面上に多数の孔が 形成されたようなほとんど同一の像を呈していた。ジクロ ロメタンによる表面性状の変化は顕著で, 研磨面の表面構 造のみならず, サンドブラスト処理によって研削された粗 䊁な表面構造をも全く消失させていた. 形成された孔の直 径は, 大方 $1 \mu \mathrm{m}$ 以下という非常に小さなものであり，レ ジンの粉末中のポリマー粒子の大きさから考えて，この孔 にポリマー粒子がはいり込むようなことはありえないが, 孔のなかにはいったモノマーは拡散, 重合するので, いわ ゆる投錨効果や表面積の増大が関与しているものと推定さ れる。しかしながら，SEMによる表面性状の形態的変化 の観察からは, SB・DM 群の值が向上したことは説明でき ず，この点は今後明らかにしなくてはならない.

DM・MMA 群については，前者による床用レジンの多 孔質化抢よび架橋ポリマーを押し広げる作用と, 後者によ る床用レジン内部へのモノマーの浸透, 拡散 ${ }^{12)}$ の相乗効果 によるものと思われる。しかしながら，モノマーの拡散が 過剰になると数多くのクラックが広範囲に生じ, 曲げ強さ が低下する ${ }^{12 \sim 14)}$ ので, 詳細については再考の余地が残さ れている.

$\mathrm{MC}$ は, 他の 2 種類の床用レジンに比べて SB 群がやや 高く, DM・MMA 群が低い傾向にあった。このことの理 由の説明は現在困難であるが, 本レジンの粉末に PMMA，BPO 以外の成分が配合してある ${ }^{15)} と と$ と何らか の関連があるかもしれない.

たわみ量については，床用レジン自体の性質に影響され

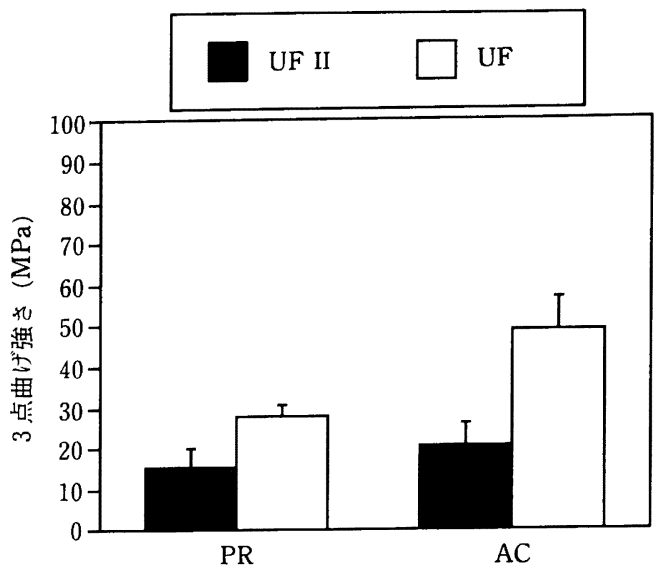

图 9 Comparison of transverse strengths of denture base resins after repair with a self-curing resin with barbituric acid derivatives and a conventional resin (final polishing surface) パルビッール酸誘導体を用いた常温重合レジンと従 来型常温重合レジンで修理後の床用レジンの曲げ強 さの比較 (軳出し研磨面)

ていた．正確に正比例するわけではないが，大方 3 点曲げ 強さが大きいほど大きい傾向にあり, 修理後の床用レジン の機械的性質を表す指標にある程度なりうるといえる。し かしながら，UFで修理した場合と異なり，床用レジン単 体のたわみ量に匹敵するような例はみられなかった。この ことは, 新しい常温重合レジン内部での凝集破壊が $\mathrm{SB}$ ・ $\mathrm{DM}$ 群に 3 例しか生じなかったこととあわせて，後述の床 用レジンに対する接着性の不足を示唆している.

PR と AC の艶出し研磨面に対して, UF II と UF で修 理したときの 3 点曲げ強さを図 9 に示した. UF II の床用 レジンに対する接着強さは, UF に比較して約 $1 / 2$ である ことがわかる．また，サンドブラスト処理後に，UF II と UF で修理したときの 3 点曲げ強さを図 10 に示した。こ の結果は, 表面処理を行っても UF II の床用レジンに対す る接着強さが, UF に比較してなお約 $1 / 2$ に止まることを 示唆している.

常温重合レジンと床用レジンの接着に関しては，両者の 成分の組成が大きく関与しているものと思われ，両者の成 分が近いもの同士の組合せでは強固に接着し，床用レジン の表面処理の効果も大きいのではないかと予想される. UF II とUFにおいて，粉末や液体の主成分に大きな変更 はないため，今回 UF IIが UF より床用レジンとの接着性 に劣っていたのは，UF IIに 3 種類の床用レジンと異なる 触媒系が採用されていることが最大の理由と推測される。 一方，今回使用した 3 種類の床用レジンと異なり，同じ系 統の触媒系を採用しているパラプレス（クルツアー社）や イントプレス (クルツアー社) ${ }^{16)}$ などの床用レジンに対し てはより強固に接着する可能性があるので，現在検討中で ある。また，UF II の硬化時間が UF のそれより短く設定 


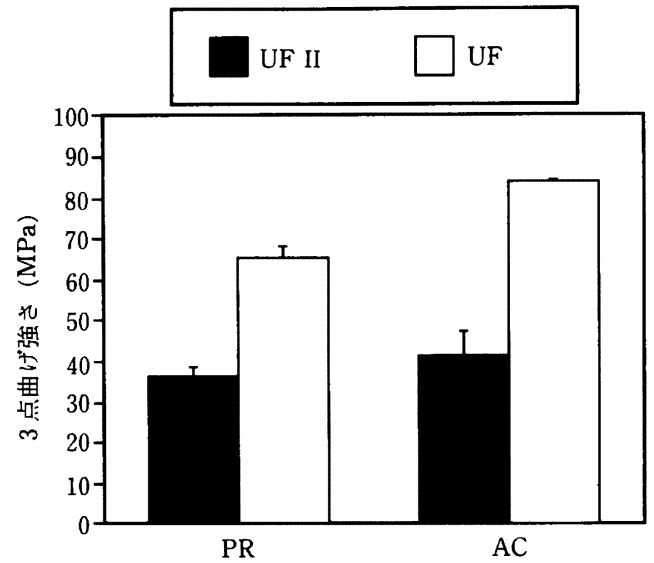

図 10 Comparison of the effects of surface treatment with alumina air-abrasive on transverse strengths of denture base resins after repair with a self-curing resin with barbituric acid derivatives and a conventional resin バルビツール酸誘導体を用いた常温重合レジンと 従来型常温重合レジンを用いて修理したときのア ルミナサンドブラスト処理の効果の比較

されているために，床用レジンと接触している部分の有効 なモノマーが存在する時間が短くなり, 浸透, 拡散効果が 低下したことが関与している可能性も想像される.

各床用レジン単体と UF II を用いた場合の SB・DM 群 の 3 点曲げ強さを図 11 にまとめて示した. PR 単体, AC 単体，および $\mathrm{MC}$ 単体の 3 点曲げ強さには差がみられた が, 表面処理後の 3 点曲げ強さにほとんど差がみられな かったため, 曲げ継手効率は PR (68\%), MC (58\%), $\mathrm{AC}(35 \%)$ の順に小さくなるという結果となった. UF を用いた場合には約 $90 \%$ の継手効率 ${ }^{3)}$ が得られたことと 比べると, UF II を用いる場合の表面処理の効果は劣って いるといえる.

今回, UF II を用いて床用レジンの修理を行う場合の有 効な表面処理法がある程度明らかになったが，その効果は 十分とは思われなかった。したがって，さらに効果的な表 面処理法を模索していく必要がある. 臨床的に問題となる のは, もともと義歯床の厚さが薄い場合をはじめ修理用レ ジンの量や厚さが全体的に確保できないような厳しい状況 や，接合部において修理用レジンが結果的に薄くなった場 合の辺縁部の剥離であるため, 修理用レジンの厚さや接合 形態との関連も重要な課題である. また, 処理効果が長期 に渡って持続するかどうかは不明であり, 接着耐久性につ いても検討が必要である。

\section{V. 結 論}

バルビツール酸誘導体を用いた新しい常温重合レジンと

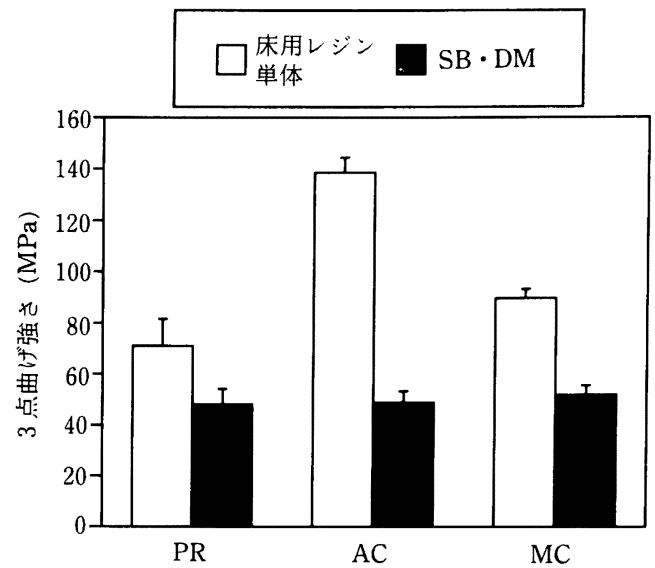

図 11 Comparison of transverse strengths of three kinds of denture base resin before and after repair with a self-curing resin with barbituric acid derivatives with surface treatment with dichloromethane followed alumina air-abrasive 3 種類の床用レジン自体とアルミナサンドブラス ト・ジクロロメタン処理後にバルビツール酸誘導体 を用いた常温重合レジンで修理したときの曲げ強 さの比較

重合様式の異なる 3 種類の床用レジンとの接着性を評価 し, さらにより強固に接着させる表面処理法を見い出すこ とを目的として検討した結果, 以下の結論が得られた.

1. 3 種類の床用レジンいずれに対しても，サンドブラ スト処理に引き続きジクロロメタン 5 秒処理を行うのが最 も効果的であった。

2. バルビツール酸誘導体を用いた常温重合レジンは, 従来型常温重合レジンに比べ，床用レジンに対する接着性 に乏しかった。

3. バルビツール酸誘導体を用いた常温重合レジンは, 従来型常温重合レジンに比べ, 床用レジンの表面処理効果 が小さかった。

本論文の要旨は, 第 97 回日本補緅歯科学会学術大会（1997 年 5 月 30 日, 長崎)において発表した。

\section{文献}

1）清水博史，羽生哲也，中 四良ほか。有機溶媒の床用レジンに 対する表面処理効果 第 1 報 各種溶媒が結合強さに及ほす影 響. 補経誌 38：119-125, 1994

2）清水博史, 中 四良, 井上弘明ほか. 有機溶媒の床用レジンに 対する表面処理効果 第 2 報 処理時間が引張り結合強さに及 保す影響. 補綴誌 $38: 706-713,1994$.

3）清水博史, 羽生哲也, 中 四良ほか。有機溶媒の床用レジンに 対する表面処理効果 第 3 報 評価法の再検討ならびに加熱重 合型と流し込み型床用レジンに対する効果の比較．補経誌 40 ： 1063-1070, 1996. 
4）星合和基，平沼謙二，川添垷涁ほか。常温重合レジン“ュニフ アストII ${ }^{\circledR ”}$ の臨床使用結果. 補緅誌 $38 ： 986-996,1994$.

5）星合和基，金澤 毅、平沼謙二ほか，常温重合レジン“ュニフ アストII の物性, 適合度について。補緅誌 $39: 494-500$, 1995.

6) Hoshiai K, Tanaka Y, Hiranuma K. Comparison of a new autocuring temporary acrylic resin with some existing products. J Prosthet Dent $79: 273-277,1998$.

7）長谷川 明, 勝誠，星合和基ほか，バルビツール酸誘導体 を用いた歯科用常温重合レジンにおける触媒の影響。補緅誌 $41: 613-619,1997$.

8）長谷川 明, 勝誠, 星合和基ほか。バルビッール酸誘導体 を用いた菌科用常温重合レジンの変色に関する検討. 補綴誌 $42: 11-19,1998$.

9）温 月姗，宮崎光治，堀部隆、マイクロ波重合法による義歯 床用レジンの理工学的性質. 福岡歯大誌 $14: 158-162,1987$.

10）安藤申直、今野一敏、長田伸一ほか，マイクロ波重合法による
アクリリックレジン床の内面適合. 歯科技エ $15: 354-362$, 1987.

11) Rupp NW, Bowen RL, Paffenbarger GC. Bonding cold-curing denture base acrylic resin to acrylic resin teeth. J Am Dent Assoc 83:601-606, 1971.

12）原嶋郁郎, 中林宣男, 平澤 忠. レジンとレジンの接着. 接着 霜学 $3: 156-164,1993$.

13）中 四良. 曲げ強さからみたレジン床義歯修理法の研究. 福岡 歯大誌 $19: 293-317,1992$.

14) Beyli MS, von Fraunhofer JA. Repair of fractured acrylic resin. J Prosthet Dent $44:$ 497-503, 1980.

15）温月姆．マイクロ波重合用レジンに関する基礎的研究．福岡 歯大誌 $18: 1-19,1991$.

16）平林 茂, 那須郁代, 原嶋郁郎ほか. 歯科用メタクリルレジン に関する研究（第 9 報）加熱重合レジン，ヒートショックレジ ン，流し込みレジンおよび常温重合レジンの組成について，歯 材器 $3: 338-349,1984$. 